\title{
Malaria-attributable fraction of fever episodes among HIV-seropositive patients in the Western highland area of Cameroon
}

\section{Timoléon TCHUINKAM ( $\nabla$ timtchuinkam@yahoo.fr)}

Vector Borne Diseases Laboratory of the Applied Biology and Ecology Research Unit (VBID-URBEA),

Department of Animal Biology, Faculty of Sciences of the University of Dschang (Cameroon) https://orcid.org/0000-0001-5593-4626

\section{François Fopa}

Centre DREAM, Hôpital Saint Vincent De Paul, Mission Catholique Sacré Coeur, BP 011 Dschang (Cameroun)

\section{Anna Maria Doro-Altan}

Department of Biomedicine and Prevention, University of Rome "Tor Vergata" (Italia)

\section{Innocent Djikolbe-Gondje}

Vector Borne Diseases Laboratory of the Applied Biology and Ecology Research Unit (VBID-URBEA), Department of Animal Biology, Faculty of Sciences of the University of Dschang, PO Box 067 Dschang (Cameroon)

\section{Maria Angeles Mendaza}

Centre DREAM, Hôpital Saint Vincent De Paul, Mission Catholique Sacré Coeur, BP 011 Dschang (Cameroon)

\section{Landre Djamouko-Djonkam}

Vector Borne Diseases Laboratory of the Applied Biology and Ecology Research Unit (VBID-URBEA), Department of Animal Biology, Faculty of Sciences of the University of Dschang, PO Box 067 Dschang (Cameroon)

\section{Francis Taafo}

Centre DREAM, Hôpital Saint Vincent De Paul, Mission Catholique Sacré Coeur, BP 011 Dschang (Cameroon)

\section{Roland Bamou}

Vector Borne Diseases Laboratory of the Applied Biology and Ecology Research Unit (VBID-URBEA), Department of Animal Biology, Faculty of Sciences of the University of Dschang, PO Box 067 Dschang (Cameroon)

\section{Armand Defo-Talom}

Vector Borne Diseases Laboratory of the Applied Biology and Ecology Research Unit (VBID-URBEA), Department of Animal Biology, Faculty of Sciences of the University of Dschang, PO Box 067 Dschang (Cameroon) 


\section{Yacouba Poumachu}

Vector Borne Diseases Laboratory of the Applied Biology and Ecology Research Unit (VBID-URBEA), Department of Animal Biology, Faculty of Sciences of the University of Dschang, PO Box 067 Dschang, Cameroon

\section{Ersilia Buonomo}

Department of Biomedicine and Prevention, University of Rome "Tor Vergata" (Italia)

\section{Mbida Mpoame}

Vector Borne Diseases Laboratory of the Applied Biology and Ecology Research Unit (VBID-URBEA), Department of Animal Biology, Faculty of Sciences of the University of Dschang, PO Box 067 Dschang (Cameroon)

\section{Research article}

Keywords: Plasmodium , Highland Malaria, HIV, AIDS, Fever episode, opportunistic disease

Posted Date: September 26th, 2019

DOI: https://doi.org/10.21203/rs.2.15204/v1

License: (c) (1) This work is licensed under a Creative Commons Attribution 4.0 International License. Read Full License 


\section{Abstract}

Background: Fever is the most frequent symptom for Malaria and HIV/AIDS, but it is non-specific; therefore it can't be used efficiently in clinical diagnosis of malaria in hyperendemic zones. In hypoendemic areas of malaria, this assertion is not obvious, since people lack naturally acquired immunity. The present study aims at determining the Malaria-attributable fraction of fever episodes (MAFE) among HIV-positive patients in a hypoendemic highland area.

Methods: During two-years prospective cross-sectional study, blood samples were collected from outpatients of an HIV/AIDS clinic and examined for the presence and density of malaria parasites. In addition to malaria related symptoms, some other patients' data were recorded: sexe, age, body mass index (BMI), T-lymphocyte CD4 counts, viral loads, haemograms and transaminases measurements.

Results: A total of 729 HIV-seropositive patients were enrolled into the study. Their mean Plasmodial infection rate and parasitaemia were: $0.823 \%$ and 1.050 parasites $/ \mu$ of blood respectively; and were both significantly lower, compared to the control seronegative group, in contrast to our hypothesis. No significant difference was observed when the mean values of transaminases were compared between those with and without plasmodial infection. For the 119 (16.32\%) febrile individuals found, the calculated MAFE was almost null (0.15\%). Their mean CD4 count, red blood cells (RBC) count and haemoglobin rate were: $226 \mathrm{cell} / \mu \mathrm{l}, 3.83 \times 106 \mathrm{RBC} / \mu \mathrm{l}$ and $10.4 \mathrm{~g} / \mathrm{dl}$ respectively; and were all significantly lower than in the non-febrile group. However, malaria parasite infection rates and mean densities were similar in both groups. Likewise, there was no difference between: sex ratios, mean ages, BMI, total white blood cells counts and viral loads between the two groups.

Conclusion: HIV infection in spite of the immunodeficiency induced does not enhance the risk of Plasmodium infection in hypoendemic highland settings. Even in the scarce cases of co-infection occurring here, malaria is rarely responsible for fever episodes. These fevers are indeed associated with higher anaemia and immunodeficiency, and likely due instead to opportunistic infectious diseases.

\section{Background}

Malaria and HIV/AIDS are responsible for high morbidity and mortality rates in endemic regions of SubSaharan Africa, where they largely overlap in their geographical distribution and remain major health concerns. Even though the infectious agents of the two pathologies share blood as biotope, their epidemiology differs a lot and depends upon the geographic region. Nevertheless, fever is the most frequent and prominent symptom for both diseases, but it is non-specific, since it can result from the release of hemozoin in malaria infections, or from opportunistic pathogens proliferation in HIV/AIDS. It is defined as a condition of the human body with temperature higher than $38^{\circ} \mathrm{C}$ [1]. As previously said, fever is the main symptom of malaria, but also a common manifestation of many infectious diseases. Malaria infection becomes a disease when parasitaemia above a certain threshold leads to the production of 
signs and symptoms [2-3]. However, in studying the specificity of highland malaria in Cameroon, it was discovered that these malaria-related symptoms vary with altitude [4]. Management of Plasmodium and HIV co-infection should therefore take into account the malaria epidemiological level of the locality.

In holoendemic areas of malaria, plasmodial infection could have effects on HIV acquisition, as well as its progression and response to therapy [5-7]. Moreover, HIV infected individuals when bearing malaria parasites, have significant increase in viral load and decrease in T-lymphocytes CD 4 count [8]. The phenomenon is even more severe in HIV infected adults [9]. Furthermore, the plasmatic viral load of HIV increases during the course of malarial episode in absence of treatment [5]. Conversely, levels of malaria parasiteamia are positively correlated to the intensity of the immunity deficit [10]. HIV/AIDS can increase the adverse effects of malaria, including anaemia and placental Plasmodium infection [11].. HIV infection may also leads to an increase of the Plasmodium parasitaemia, along with the frequency of clinical malaria; probably by suppressing the anti-Plasmodium immunity of the infected subjects [12-16]. In fact, viral infection induces cellular destructions, which lead to a decrease in T-CD4 lymphocytes, as well as in their function within the cellular mediated immunity response [17]. This disruption of the acquired immune response also affects incidence, frequency, severity and even the efficacy of anti-malarial drugs [17-19]. It is important to note that in hyperendemic zones of malaria, HIV leads to an increase of malaria parasitaemia, thus inducing an increase of the infectious reservoir within the human population and the subsequent transmission rate of malaria [05], though a trend of increase in transmission-blocking immunity was observed with rising gametocytaemia in the general population [20]. These observations raise the question of possible interactions between the two pathogens in holoendemic areas, already discussed but still unclear [21]. However, in hypoendemic zones like highlands where malaria transmission and incidence are low, and populations are instead prone to epidemics, interactions between Plasmodium and HIV in case of co-infection have not yet been studied.

There are concerns that where HIV prevalence is high, co-infection of HIV and Plasmodium does exist [22], and the use of antiretroviral drugs (especially protease inhibitors), in some cases inhibits liver stage parasites at clinically relevant concentration [23], and in other cases can affect the efficacy of the newly introduced artemisinin-based combination therapy (ACT) [24]. The impediment in this situation is that, simultaneous administration of anti-malarial with anti-retroviral treatments can lead to high level of toxicity [25-26]. Treatment of HIV and Plasmodium co-infection is therefore a critical issue, and should be considered as medical emergency.

Liver involvement in Plasmodium infection and the subsequent function-abnormalities or dysfunctions are common in severe malaria and may manifest as elevated liver enzymes or hyperbilirubinemia [2728]. In fact, infection of liver cells can cause organ congestion, sinusoidal blockade and cellular inflammation. These changes in hepatocytes can lead to the leakage of parenchymal transaminases and membranous phosphatase enzymes of the liver into the blood circulation [29]. It has been shown that if malaria is neglected or not treated properly, there will be an increase in the blood level of transaminases which will cause damage to the liver cells [30]. As mentioned above, hepatocellular dysfunction is frequent in malaria, but that qualifying as malarial hepatopathy is not common. It appears mostly in case 
of severe malaria and is more likely to occur in presence of other complications [31]; hence coinfection with HIV could favour its development. Moreover, individual-specific factors may confer more or less susceptibility to hepatocyte injury [32]. The importance of proving whether or not Plasmodium infection induces greater hepatocellular disease in immunodeficient people is of great consequence, because if such were the case, these patients should be treated for hepatitis as well as malaria.

Following the release of metabolic wastes present in the digestive vacuole of Plasmodium (from the rupture of infected erythrocytes) into blood circulation during malaria attack, hemozoin is engulfed and accumulated within circulating monocytes and tissue macrophages (reticulo-endothelial system). It mediates the release of endogenous pyrogens that altered several functions of the immune system; especially thermoregulation [33]. This hemozoin accumulation is associated with some malarial symptoms, mainly fever. In fact, high levels of hemozoin within immune cells have been shown to correlate with disease severity [34-35]. However, the physiopathology of the host-parasite interactions and particularly the mechanism of fever induction in malaria have not been clarified yet. The slight progress made until recently, about the potential mechanism of malaria-induced fever reports on a novel mechanism that the host uses to recognise Plasmodium DNA via a Toll-like receptor (TLR-9). It has elucidated an important step in the long-time discussion on why and how does malaria cause fever, by showing that hemozoin internalises plasmodial DNA and present it to TLR9. Plasmodial DNA then intracellularly interacts with TLR9, initiating signal transduction leading to the release of proinflammatory cytokines. These cytokines induce production of prostaglandins which subsequently leads to induction of fever. Hemozoin is therefore involved in malaria fever but is toll-free [36]. This discovery corrects previous findings claiming that hemozoin was a direct TLR9 stimulus, and that stimulation of TLR-9 by hemozoin pigment could be the key step for inducing fever in human host during malaria attack [37]. Some authors have pointed out a production of prostaglandins that are pyrogenic and immunosuppressive, by both the human host cells and Plasmodium themselves [38]. It is likely that these important mechanisms of malaria physiopathology may also apply to opportunistic infectious diseases in people living with HIV (PLHIV). Anyhow, more knowledge on the fever physiopathology is needed in order to discriminate the sources of fever in co-infected patients, and develop intervention strategies towards reducing the disease burden.

Fever episodes are usually attributed to malaria in endemic zones of Sub-Saharan Africa, because the case definition of symptomatic malaria generally used is fever associated with a specific parasite density threshold [30-31, 39-40]. For this reason, it has been recommended for quite a long time that for all febrile episodes, a presumptive treatment should be administered [41]. The approach was of value to clinicians, but not to epidemiologists. In fact, it is not clear so far, whether the presumptive treatment of fever episodes as malaria cases is an advantage or a hindrance for malaria control [42]. Recently, with achievement of the rapid diagnostic test that enable quick and easier examination of blood, WHO moved away from presumptive treatment to one that advocates parasitological diagnosis whenever possible [43]. The aim of this shift of policy was to avoid treating large numbers of non-malarial fevers, which represent a non-negligible fraction in holoendemic areas, in contrast to highlands. The potential benefits of parasitological diagnosis will depend mainly upon the prevalence of Plasmodium infection among 
patients who report fever $\left(P_{f}\right.$ knowing that these malarial fevers are always associated to other manifestations [44-45]. Unfortunately, this policy is not practically implemented in most places. Yet, treatment of fever in our hyperendemic region ought to be done with extreme caution, since several infectious diseases also generate fever; especially opportunistic diseases in people living with HIV infection (PLHIV). In fact, a bright confusion surrounds the definition of fever and its use in clinical diagnosis of malaria [46-49]. For some authors, fever or any recent febrile episode strongly predicts a malarial infection [22]; while for others, it is more likely associated to an infectious disease [50]. Nevertheless, it is intuitively obvious that PLHIV in malaria hyperendemic zones will present an increased risk of developing malaria, since their immune system is deficient [11-14]. However, very little is known about hypoendemic areas.

Since the prevalence of malaria among PLHIV was not known in the hypoendemic area of WesternCameroon highlands, it was important to make a distinction between Plasmodium-induced fever and the others, for a better treatment policy of these peculiar patients. This study aimed principally at evaluating the malaria-attributable fraction of fever episodes (MAFE) among HIV-seropositive patients in the Western-Cameroon highland.

\section{Methods}

\section{Study site}

This prospective cross-sectional study was conducted in Dschang $\left(05^{\circ} 27^{\prime} \mathrm{N} ; 10^{\circ} 04^{\prime} \mathrm{E}\right)$, the county town of Menoua Sub-Division in the Bamiléké Highland plateau (Western Region of Cameroon), at approximately $1,400 \mathrm{~m}$ of altitude. The landscape is made up of bush savannah with an altitudinal Soudano-guinean climate comprising 2 main seasons: a rainy season (from mid-March to midNovember) followed by a dry season (from mid-November to mid-March). The average rainfall is 2,000 $\mathrm{mm}$ with relative humidity between 64.3 and $97.0 \%$. The daily mean temperature is $20^{\circ} \mathrm{C}$ with variations exceeding $2.2^{\circ} \mathrm{C}$ [51]. The population of Dschang was estimated at 120,207 people [52].

The field study was conducted for two years at the Saint Vincent De Paul Hospital, which hosts among other services, a care and treatment centre for PLHIV named DREAM (Drug Resource Enhancement against AIDS and Malnutrition). The DREAM Centre was initiated by the Sant' Egidio Christian community and the Daughters of Charity; and subsequently authorized by the Ministry of Public Health of Cameroon as the western regional reference diagnostic and treatment centre for HIV/AIDS.

For each participant, a semi-quantitative examination of slide (+ system) to quickly provide the physician with rough laboratory result, and enable him taking the right and informed decision for the treatment was conducted at the laboratory of Saint Vincent de Paul Hospital. Patients were then monitored accordingly. Plasmatic viral load, biochemistry, haematology and CD4 cells count were later determined at the molecular biology laboratory of the DREAM centre. The quantitative analyses of slides were carried out at 
the Vector Borne Diseases Laboratory of the Applied Biology and Ecology Research Unit (VBID-URBEA), to determine the malaria parasite species and densities.

\section{Sampling Methods and patients management}

Outpatients of the Hospital Saint Vincent De Paul were on daily basis systematically requested by the physician to participate in the present study, after being instructed on the protocol's objectives and methods. Those aged over 15 years who agreed were selected and enrolled into the study; they were then tested for HIV and Plasmodium carriage. All the patients recruited on Wednesdays were exceptionally enrolled into the study, irrespective of the results of their malaria and HIV test to generate a sero-negative control group, while only the HIV-positive individuals of the other days of the week were considered. In addition to these sets of participants, patients diagnosed HIV-positive in other clinics over the whole western region were referred to the DREAM center with the record of their clinical data, as DREAM was accredited as the reference centre of the region for free of charge treatment. Cotrimoxazol prophylaxis, antiretroviral and antimalarial treatments (whether medically prescribed by physician or simply by automedication) prior to the patients' visit to the hospital were exclusion criteria for enrolment of patients into this article.

Patients were subsequently put under treatment and monitored, depending on the results of laboratory tests: a first line antiretroviral treatment (ARV) in case of CD4 cells count $<350 \mathrm{cell} / \mu \mathrm{l}$ or viral load $>$ 100,000 copies/ $\mathrm{ml}$ as recommended by the government policy, and an artemisinin combination therapy (ACT) in case of any single presence of Plasmodium. However, only data collected during the first visit of the outpatients (i.e.: before the beginning of any antiretroviral or antimalarial treatment) were considered for this article.

Axillaries' temperatures and the other symptoms were recorded on this first day of consultation, to enable separation of patients into 2 groups: febrile (and/or symptomatic) and non-febrile, based on the definition of malaria related symptoms in this locality [32]. Weights $(w)$ of patients were recorded using a personal weighing machine, while the height $(h)$ was measured with a height gauge. The two parameters were used to calculate the Body Mass Index (BMI), which enable appreciating the nutritional status of patients using De St Paul's formula [53]:

[Due to technical limitations, this equation is only available as a download in the supplemental files section.]

Blood sampling of those who consented was done as prescribed by the doctors for routine check and management of HIV infection at the DREAM centre, and malaria diagnosis. No additional blood sample was required for this research. In this respect, blood was obtained by classical venous puncture, into two tubes: a $5 \mathrm{ml}$ vacutainer tube containing EDTA for haemogram, CD 4 count, viral load, thick and thin blood films; and a $8 \mathrm{ml}$ dry tube for biochemical analyses. 


\section{Laboratory examinations}

Thick and thin blood films for the microscopic examination of malaria parasites were prepared manually [54]. Slides were then examined under the immersion oil objective 100x, for the presence and density of Plasmodium. A thick blood film was considered negative when no parasite was seen after examining 200 fields [55]. For the positive slides, identification of the parasite species was done on the thin blood smear. To calculate the density of asexual parasite stages, the number of trophozoites observed for 200 white blood cells (WBCs) was recorded; whereas the density of sexual parasite stages was obtained by counting the number of gametocytes observed for 1,000 WBCs. The average densities of asexual and sexual parasites were obtained based on the number of WBCs counted per unit volume of blood on the haemogram of each patient. The haemogram was realised with a haematologic counter [56]. CD4 cells count was realised using a cytometer [57]. Measurement of plasmatic viral load was done with the 340 Bayer branched DNA technology system (VERSANT HIV-1 RNA 3.0 Assay bDNA, Siemens Diagnostics) with a limit range of detection between 50 to 500,000 RNA copies/ml [58]. There are several liver enzymes whose concentration in the blood increases during the course of Plasmodium infection [27-30], however, only two were selected for this study. Titration of transaminases (Glutamo-oxalo-acetate transferase (GOT) and Glutamo-pyruvate transferase (GPT)) was realised on serums, using the automate Humastar180 [59], in order to assess the impact of Plasmodium infection on the liver function of PLHIV.

\section{Malaria-attributable fraction estimate of fever episodes among the seropositive patients}

Just as for the clinical case definitions of malaria, there have been several attempts for estimating the fraction of fever episodes attributable to malaria [47, 60-64]. Herein the fraction of fevers and/or the other malaria-related symptoms attributable to malaria infection was calculated as:

[Due to technical limitations, this equation is only available as a download in the supplemental files section.]

where $P_{f}$ is the proportion of fever episodes with parasites present, and $P_{a}$ the proportion of asymptomatic but parasite positive individuals sampled from the general population [62].

\section{Statistical Analysis}

Data collected were recorded and handled using a Microsoft Excel software program 2010. Analysis of data was performed using the statistical package for social sciences (SPSS) software (PASW Statistics version 18).

The Chi-Square $\left(x^{2}\right)$ test was first of all used to compare the prevalence of the malaria infections, the sex/ratio between HIV positive and negative patients, and finally to compare the sex/ratio between febrile 
and non-febrile HIV-positive participants.

After a logarithmic transformation of data, the student $t$ test allowed comparing geometric means of Plasmodium parasitaemia first of all between HIV-positive and HIV-negative patients, and then between HIV-positive febrile and non-febrile patients. This same test was used to compare means of temperature, age, WBCs, RBCs, Viral Load, CD4, Hb and BMI between febrile and non-febrile HIV-positive participants.

The Mann-Whitney non-parametric $U$ test was used to compare means of T-CD4, Viral load, BMl, as well as means of GOT and GPT, between HIV seropositive patients co-infected with Plasmodium, and HIV positive patients not infected with malaria parasite.

All the different tests were calculated at $95 \%$ Confidence Interval $(\mathrm{Cl})$ and the differences were considered significant for $\mathrm{p}<0.05$.

\section{Results}

A total of 1960 thick blood smears were realized during the course of the study, with 729 (37.2\%) from HIV-positive patients and 1231 (62.8\%) from HIV negative patients.

\section{Comparison of HIV-positive and HIV-negative patients}

HIV-positive participants were significantly older than HIV-negative ones with average ages of 34.7 and 25.7 years old respectively $(p<0.001)$. The higher mean age for HIV-positive group confirms the fact that HIV mostly affects the sexually active population group. The sex-ratio was 0.39 and 0.66 for seropositive and seronegative participants respectively, with a significant difference between the 2 groups $(p<0.001)$, indicating that female positive patients attend hospitals more frequently than men do; which is not the case in the seronegative group (Table 1). On the contrary, the rate of febrile episodes and the mean temperatures did not differ between the two groups, meaning that the febrile status of the HIV-positive and HIV-negative patients were similar ( $p=0.31$ for the prevalence of feverish people, and $p=0.76$ for the mean temperature). Following clinical consultation of outpatients by the physician, 98 (13.4\%) patients were admitted in the hospital (for at least one day) among the seropositive patients, versus $186(15.1 \%)$ in the seronegative group, with a non significant difference $(p=0.31)$.

In spite of the similarity in the severity of disease, as revealed by the malaria-related symptoms (fever, headache, joint pains, convulsion and nausea, except for abdominal pain), prevalence of Plasmodium infections were $0.823 \%$ and $8.204 \%$ in HIV-positive and HIV-negative participants respectively, with a significant difference between the 2 groups $(p<0.001)$. This shows that on the contrary to our hypothesis, HIV-positive patients are not more prone to malaria infection than the seronegative ones. Mean malaria parasitaemia was also significantly low among seropositive patients compared to seronegative individuals $(p<0.001)$. Thus, HIV infection does not constitute a risk factor for malaria 
infection in hypo-endemic areas; neither does it predispose patients to high malaria parasite loads (Table 1).

\section{Effect of Plasmodial infection on the liver function of PLHIV}

Measurements of liver enzyme secretions were done for 490 HIV-positive patients, whose cases were considered serious. No significant difference was observed when comparing the mean values of GOT and GPT between the seropositive patients infected by Plasmodium and those who were Plasmodium free ( $\mathrm{p}$ $=0.87$ for GOT and 0.63 for GPT). Malaria infection seemed not to have any influence on the secretion of these transaminases and therefore on the liver function of PLHIV, at least at the beginning of their sickness (Table 2).

\section{Comparison of febrile and non-febrile HIV-positive participants}

Among the 729 seropositive patients recruited, 119 (16.3\%) were febrile (Body Temperature $\geq 38^{\circ} \mathrm{C}$ and/or other symptoms associated with malaria in this locality, such as: chills, headache, body pains, etc) [4]. Mean temperatures were $38.59^{\circ} \mathrm{C}$ and $36.72^{\circ} \mathrm{C}$ in febrile and non-febrile groups respectively (Table 3$)$, with a significant difference $(p=0.001)$. No significant difference was observed as mean age and sex-ratio between the two groups were concerned ( $p=0.08$ and $p=0.17$ respectively). Increase of temperature among HIV-infected patients was therefore neither related to the age nor to the gender of patients.

Means of viral loads were $2.14 \times 10^{5}$ and $1.81 \times 10^{5}$ copies $/ \mathrm{ml}$ in the febrile and non-febrile seropositive groups respectively, and no significant difference was observed between the 2 groups $(p=0.28)$. However, when these seropositive patients were divided into high ( $>100,000 \mathrm{copies} / \mathrm{ml})$ and low viral loads ( $\leq 100,000$ copies $/ \mathrm{ml}$ ), the proportion of individuals with heavy viral load was significantly higher in the feverish group than in the non febrile group, $57.1 \%$ and $43.8 \%$ respectively $(p=0.02)$. Fever episodes in PLHIV could have been indirectly induced by heavy viral loads, or eventual opportunistic diseases.

When comparing the mean of total WBCs between the seropositive febrile and non-febrile individuals, no significant difference was observed, as the different means were $5.2 \times 10^{3}$ and $5.7 \times 10^{3}$ leucocytes $/ \mu \mathrm{l}$ respectively $(p=0.57)$. Thus, the febrile status of seropositive patients did not have impact or didn't derive from the WBCs density (Table 3). However, the means of CD 4 cells numbers were 226 and 305 cells/ $\mu \mathrm{l}$ respectively for HIV-positive febrile and non-febrile individuals $(p<0.003)$. Moreover, the rate of people with low CD4 cells count $(<350 \mathrm{cell} / \mu \mathrm{l})$ was significantly higher in the feverish group than in the non febrile group, $83.2 \%$ and $71.5 \%$ respectively $(p<0.007)$. The febrile patients were significantly more immune-depressed than non-febrile ones, and this suppression concerns exclusively the CD4 cells category. 
The mean densities of haemoglobin were 10.37 and $11.36 \mathrm{~g} / \mathrm{dl}$ in febrile and non-febrile seropositive patients, and those of RBCs were $3.83 \times 10^{6}$ and $4.03 \times 10^{6}$ cells $/ \mu$ respectively. Anaemia was significantly marked in febrile seropositive individuals compared to non-febrile ones $(p<0.001$ for haemoglobin and $p$ $<0.005$ for RBCs) (Table 3). It is obvious that haemolysis of parasitized red blood cells is likely to induce anaemia and fever; but it is difficult here to tell the origin of anaemia and therefore the relationship between fever and anaemia. In fact, anaemia could also arise from: chronic diseases, severe immunedepression and failure or diminishing of bone marrow production.

The means of BMIs were 23.80 and 23.37 respectively for HIV positive febrile and non-febrile individuals, with no significant difference $(p=0.36)$ (Table 3$)$. The weight loss observed in HIV positive patients here and there was not responsible or due to their feverish status.

As the prevalence of malaria infection is concerned, no significant difference was observed between the febrile and non-febrile HIV-positive groups, $0.840 \%$ and $0.819 \%$ respectively $(p=0.65)$. Also, there was no significant difference regarding the mean of plasmodial parasitaemia between febrile and non-febrile seropositive participants; about 01 trophozoite/ $\mu$ in each group $(p=0.74)$ (Table 3). Fever cannot be used therefore as an indicator of Plasmodial infection in PLHIV.

\section{Malaria-attributable fraction estimate of fever episodes}

Clinical examination data of all the 729 seropositive patients were recordered and 119 (16.3\%) were febrile and/or carried malaria-like symptoms [32]. Among this group of feverish people, only one person was infected with Plasmodium after parasitological examination (Table 3). The prevalence of Plasmodial infections in febrile HIV-positive patients $\left(P_{f}\right.$ was therefore $1 / 119=0.840 \%$.

Among the 729 seropositive patients, only 5 were Plasmodium positive and without malaria-like complaint; indicating a malaria infection prevalence within the asymptomatic patients of $5 / 610=0.819 \%$ and a $P_{a}$ equal to $5 / 729=0.686 \%$. Based on Smith's formula the MAFE was therefore estimated to be:

[Due to technical limitations, this equation is only available as a download in the supplemental files section.]

\section{Discussion}

This study evaluates the malaria-attributable fraction of fever episodes among HIV seropositive patients in Dschang, a town in the highland area of the Bamiléké plateau in western region of Cameroon, with hypoendemic peculiarities as far as malaria epidemiology is concerned [32,65]. The protocol design was tested and approved in the framework of a concomitant study, aiming at evaluating the feasibility and effectiveness of a triple ARV therapy for prevention of mother-to-child transmission at the DREAM centre [66]. 
The higher mean age in HIV-positive patients compare to the HIV-negative group confirms the fact that HIV mostly affects the sexually active age range of the population. This result is similar to the one observed previously in Bamako, where young adults with mean age between 26 and 36 years were more infected by HIV than the other age groups [67]. Moreover, within the HIV-positive group of patients, the sex-ratio was found to be in favour of women (0.39). This may indicate that the number of HIV-infected women was higher compared to men, or that women undergo HIV screening more often than men do.

\section{Malaria infections in seropositive and seronegative patients}

In a previous study in the same area, a list of malaria-related manifestations was determined: headache, joint pains, abdominal pains, convulsion and nausea [4]. A comparison of the frequencies of each of these symptoms in the seropositive and seronegative groups was made here, and apart from the abdominal pain whose frequency was higher in the seropositive group, no other symptom's frequency was significantly different between the two groups. Seropositive and seronegative outpatients of this hospital located in a malaria hypoendemic area are therefore symptomatologically similar at their arrival in the clinic, which for most of this sample correspond to the beginning period of their immuno-deficiency status, except for the abdominal pain.

The lower prevalence and density of malaria parasite in HIV-positive participants indicate that HIV infection does not predispose patients to Plasmodium infections early. A study realised in South Africa, also reported a better survival in a rural population infected by HIV, and pointed out that malaria did not represent an important cause of morbidity in PLHIV [68]. This observation confirms the report that immunodeficiency due to HIV does not affect immunity to malaria quickly [69]. In fact, the data analysed for this article were collected during enrollement of patients into the cohort study of DREAM. For some of them, this was even the visit of revelation and awareness of their HIV immune status. In absence of treatment, it is likely for some authors that HIV will gradually reduce the immune response to malaria and that this reduction will be more pronounced with the progressing level of immune-depression [12-16]. More case studies are therefore necessary to explore the effect of HIV infection on the susceptibility of subjects to malaria infections and the interaction between the two pathogens in case of long term coinfection. Hence, monitoring of the DREAM cohort of HIV-positive patients will unveil their viral and immune evolution under first line ARV treatment, as well as the outcome of eventual coinfection with Plasmodium at a more immunodeficient stage.

\section{Effect of Plasmodial infection on the liver function of PLHIV}

Increase in the level of transaminases in the blood indicates a possible cell lesion in the liver and its subsequent dysfunction; however none of the transaminases is specific for liver function assessment in Plasmodium infection, although liver dysfunction has long been recognized as a clinical feature of malaria. In this study, two types of transaminases were arbitrarily targeted: the GOT and the GPT. Absence of difference in GOT and GPT between the seropositive individuals infected by Plasmodium and 
those without malaria parasite was not surprising, since the patients were suffering mostly from uncomplicated falciparum malaria. Moreover, the proportion of patients clinically diagnosed as seriously sick and admitted into the hospital was comparable in the two groups. In fact, hepatocellular dysfunction occurs frequently rather in severe malaria, and malarial hepatopathy have significant association instead with the duration of sickness (hospitalization) [27]. Unfortunately, this article does not include the data from the ongoing cohort monitoring at the DREAM centre. There is a need for more investigations to search how co-infection of Plasmodium and HIV impacts the functioning of liver, in case of untreated or neglected severe malaria.

\section{Comparison of febrile and non-febrile HIV-positive patients}

The HIV-positive patients were divided into two groups: febrile patients (with temperature $\geq 38^{\circ} \mathrm{C}$ and/or other malaria-related symptoms) and non-febrile patients. Febrile HIV-seropositive patients showed lower CD4 cells count than non-febrile positive individuals. However, the prevalence of Plasmodium infection among outpatients was very low; therefore very few patients were co-infected with malaria parasites and HIV in both groups. This means that reduction of CD4 lymphocytes predisposes HIV-patients instead to opportunistic infections that finally cause their febrile status. For example, a study carried out in a locality of Uganda with higher incidence for the two diseases than in Western-Cameroon, pointed an association between fever and co-infection of malaria and AIDS [11]. Similar result was previously observed, demonstrating that fever episodes in seropositive patients are usually caused by dissemination of opportunistic infections, and that the relative frequency of each causative agent is influenced by many factors among which are: the number of CD4 lymphocytes, the geographical position of the locality and the local prevalence of the infectious agents responsible [70]. It should be noted that in the malaria hypoendemic area of the Bamiléké plateau in Western-Cameroon, where people are expected to lack efficient protective immunity, malaria is not an opportunistic disease for PLHIV.

The mean of haemoglobin density being 10.37 and $11.36 \mathrm{~g} / \mathrm{dl}$, and that of RBCs $3.83 \times 10^{6}$ and $4.03 \times 10^{6} /$ $\mu \mathrm{l}$ respectively for HIV febrile and non-febrile subjects, it could be assumed that seropositive febrile patients were more susceptible to haemolytic infections than non-febrile ones. Though it is obvious that haemolysis of red blood cells is likely to induce fever, it is difficult here to determine the origin of anaemia and therefore the relationship between anaemia and fever. In fact, apart from haemolysis, there is a multitude of potential causes for anemia and reduced number of erythrocytes. The decrease of haemoglobin and RBCs during the course of HIV infection could also be an indication of advanced immune-depression, failure or diminished bone marrow production, or other concomitant chronic disease; which result in the increased infection susceptibility to opportunistic diseases and the subsequent fever. Similar results were obtained in a malaria endemic area, and asserted that opportunistic infectious agents are often responsible for anaemia and hyperthermia in HIV seropositive patients [71]. This anaemia could also be due to ARV therapy, especially with Azidothymidine (AZT), which causes bone marrow suppression [72]. However, patients already under malaria or HIV treatment were excluded for this article. The febrile status of HIV-positive patients was independent of the age, the gender, the viral load, 
the total WBCs count and the BMI. Herein, it is shown that malaria parasites should not be incriminated for anaemia and fever occurrences, since the Plasmodial infection rate and parasitaemia were very low in both groups and not correlated to the increase of temperature.

\section{Malaria-attributable fraction of fever episodes}

Malaria-associated symptoms in outpatients of this health center were previously described [32], and its definition used in this study, to estimate the fraction of fever episodes attributable to Plamodium infection. In fact, it has been demonstrated that the MAFE varied with the locality, the season and the age range [47]. This estimation among PLHIV was found to be very low here among PLHIV; meaning that on the contrary to holoendemic areas, Plasmodium are rarely responsible for fever episodes among people of hypoendemic highlands living with HIV. Their symptomatic and anaemic status found is therefore more likely due to opportunistic infectious diseases.

A study realized in Malawi on the attributable-fraction of malaria in febrile episodes, showed that $15 \%$ of reported fevers in HIV-positive subjects were due to Plasmodium infection [50]. Another study carried out in Ghana revealed that, the prevalence of confirmed malaria by the laboratory was $4.4 \%$ in seropositive patients [8]. The above mentioned estimates found in seropositive patients of endemic areas were both higher than the value obtained here in Western highland of Cameroon, which was $0.15 \%$. Surprisingly, this value of MAFE was too low compared to the $P_{f}$ in the general outpatients of the Saint Vincent De Paul Hospital in the same site, for which a high value of $P_{f}(75.8 \%)$ was found [32]. In this former publication, participants were all enrolled from the Saint Vincent De Paul Hospital and none at the DREAM center, and even less than 15 years were included. They were then sample representative of the local general population. For this article, the sample population is constituted by individuals either suspected or confirmed for HIV infection; they are known to have the propensity to automedication of all kind, due to their frequent discomfort, which could reduce their plasmodial infection rate. Another possible reason of this discrepancy is that since that study, two rounds of mass distribution campaign of long lasting insecticides impregnated bed nets have been launched by the national malaria control programme. It is therefore confirmed that malaria is not an opportunistic disease in PLHIV on the Bamileké plateau.

Herein, we are concerned with a hypoendemic highland malaria zone with a low level of transmission of around 62.8 infective bites/human/year [65] and a relatively low HIV infection rate of 2,8\% [73]. These are possible reasons why the MAFE was almost null. On the contrary, it is difficult in holoendemic settings to distinguish between fever from Plasmodium infection whose rate is somehow high despite the existence of asymptomatic cases [60,62], and that induced by other causes; even after malaria parasite have been diagnosed in the patient. In fact, in holoendemic areas, some people are normally asymptomatic Plasmodium carriers and subsequently develop fever due to opportunistic infection. The strong controversy around the use of fever (and/or the other malaria associated symptoms) to define malaria cases in holoendemic areas among PLHIV [21], does not exist here on the Bamileké plateau therefore. 


\section{Conclusion}

The present study revealed that HIV infection in spite of the immunodeficiency induced does not enhance the risk of Plasmodium infection in hypoendemic highland settings. Even in the scarce cases of coinfection, damage induced by Plasmodium on the patients' liver function is not obvious, and malaria represents a negligible fraction of the febrile episodes. These febrile episodes which are associated with higher anaemia and immunodeficiency, are therefore likely due to opportunistic infectious diseases. As a matter of fact, malaria is not an opportunistic disease for people of this highlands living with HIV. We argue that the seropositive patients were instead highly susceptible to other infectious diseases which were responsible for their symptomatic status. The definition of malaria based on fever (and/or the other malaria associated complaints), in this case would mislead clinical diagnosis of opportunistic diseases, which in a large proportion will be wrongly treated as malaria.

\section{Abbreviations}

ACT: Artemisinin-based combination therapy; AIDS: Acquired immune deficiency syndrome; ARV: Antiretroviral treatment; BMI: Body mass index; DREAM: Drug resource enhancement against AIDS and malnutrition; GOT: Glutamo-oxalo-acetate transferase; GPT: Glutamo-pyruvate transferase; HIV: Human immunodeficiency virus; MAFE: Malaria-attributable fraction of fever episodes; PLHIV: People living with HIV; RBC: Red blood cell; TLR: Toll-like receptor; VBID: Vector Borne Diseases Laboratory; WBC: White blood cell; WHO: Word health organisation.

\section{Declarations}

\section{Acknowledgements}

We are very grateful to the personnel of the Hôpital Saint Vincent De Paul, the DREAM Centre, as well as the Health District authorities, for their collaboration and support. We acknowledge the laboratory facilities placed at our disposal by the DREAM Centre. We particularly thank Dr Tabi Oben and Mr Irenée Domkam for their assistance in the statistical analysis of data.

\section{Funding}

This investigation was initiated with the help of "Jeune Equipe Associée IRD" (JEA-IRD) and received financial support under the Multilateral Initiative on Malaria (MIM) Project A50085, through the UNICEF/UNDP/World Bank/WHO Special Programme for Research and Training in Tropical Diseases (TDR).

\section{Availability of data and material}

Not applicable. 


\section{Authors' contributions}

TT, AMDA and MM conceived, designed and planned the study. FF was the PhD student of the project; he monitored the field and the laboratory studies, assembled and analyzed the data, then drafted the manuscript. IDG, RB, ADT and LDD were Master students in charge of biological materials and data collection for the VBID. They assisted in all the field and laboratory manipulations. MAM, AMDA and EB monitored the cohort of patients. FT was the medical Doctor in charge of consultations and informed consent of patients. All authors revised the manuscript critically, then read and approved the final version.

\section{Ethics approval and consent to participate}

A national ethical clearance ( $N^{\circ}$ : FWA IRB00001954) was delivered to the research team by the National Ethics Committee (Yaoundé, Cameroon). The administration staffs of Saint Vincent De Paul Hospital and DREAM centre gave their approval for collaboration in the study. The free and informed consent of patients was requested through individual discussions and group meetings with patients. For those willing to cooperate, a written informed consent was obtained, prior to their enrolment in the study, and only participants who filled and signed the consent form after being clearly informed about the study protocol were enrolled. Free treatments with artemether-lumefantrine (Coartem $\AA$ ) were given to participants in case of positive diagnosis of Plasmodium, as recommended by the Ministry of Public Health, while HIV-positive patients followed the ARV treatment according to the national standard of care.

\section{Consent for publication}

Not applicable.

\section{Competing interests}

The authors declare that they have no competing interests.

\section{References}

1. Blok L, Cereceda M, Gastellu-Etchgorry M, Henkens M, Rigal J, De Semet M, Weiss F, Grouzard V: Guide clinique et thérapeutique pour les programmes curatifs des hôpitaux et des dispensaires à usage des prescripteurs. 7ème édition Médecins sans frontière ; pp 26.

2. Koram KA, Molyneux: When is "malaria" malaria? The different burden of malaria infection, disease, and malaria-like illnesses. Am J Trop Med Hyg 2007, 77 (Suppl 6): 1-5.

3. Molyneux M: When is "malaria" malaria? In abstract from the fourth MIM Pan-African malaria Conference, Yaounde.; 13-18 Nov 2005. Acta Tropica 2005, 95S: 1-506. 0.114. 
4. Tchuinkam T, Nyih-Kong B, Fopa F, Simard F, Antonio-Nkondjio C, Awono-Ambene HP, Guidone L, Mpoame M: Distribution of Plasmodium falciparum gametocytes and malaria-attibutable fraction of fever episodes along an altitudinal transect in western Cameroon. BMC Malar J 2015, 14: 15.

5. Hoffman IE, Jeres CS, Taylor TE, Munthali P, Dyer J, Wirima J: The effect of Plasmodium falciparum malaria on HIV-1 RNA blood plasma concentration. AIDS 1999, 13: 487-494.

6. Modjarrad K, Vermund SH: Effect of treating co-infection on HIV-1 viral load: a systematic review. Lancet Infect Dis 2010, 10: 55-463.

7. Cuadros DF, Branscum AJ, Crowley PH: HIV-malaria co-infection: effects of malaria on the prevalence of HIV in East sub-Saharan Africa. Int J Epidemiol 2011, 40: 931-939.

8. Adu-gyasi D, Fanello C, Baiden F, Porter DH J, Korbel D, Adjei G, Mahama E, Manu A, Asante KP, Newton S, Owusu-Agyei S: Prevalence of clinically captured confirmed malaria among HIV seropositive clinic attendants in five hospitals in Ghana. BMC Malar J 2013, 12: 382-389.

9. Mermin J, Ekwaru JP, Liechty CA, Were W, Downing R, Ransom R, Weidle P, Lule J, Coutinho A, Solberg P: Effects of co-trimoxazole prophylaxis, antiretroviral therapy, and insecticide-treated bednets on the frequency of malaria in HIV-1-infected adults in Ugandan: a prospective cohort study. Lancet 2006, 367: 1256-1261.

10. Whitworth J, Morgan D, Quigley M, Smith A, Mayanja B, Eotu H, Omoding N, Okongo M, Malamba S, Ojwiya A: Effect of HIV-1 and increasing immunosupression on malaria parasitaemia and clinical episodes in adults in rural Uganda: cohort study. Lancet 2000, 356: 1051-1056.

11. Ayisi JG, van Eijk AM, ter Kuile FO, Kolczak MS, Otieno JA, Misore AO, Kager PA, Steketee RW, Nahlen $\mathrm{BL}$ : The effect of dual infection with HIV and malaria on pregnancy outcome in western Kenya. AIDS 2003, 17: 585-594.

12. Berg A, Patel S, Aukrust P, David C, Gonca M, Berg E S, Dalen I, Langeland N: Increase severity and mortality in adults co-infected with malaria and HIV in Maputo, Mozamnique: a prospective crosssectional study. PLOS One 2014, 09 (2) e88257.

13. Chalwe V, Van Geertruyden J-P, Mukwamataba D, Menten J, Kamalamba J, Mulenga M, D’Alessandro: Increase risk for severe malaria in HIV-1-infected adults, Zambia. Emerg Inf Dis 2009, 15: 749- 758.

14. Cohen C, Karstaedt A, Frean J, Thomas J, Govender N, Prentice E, Dini L, Galpin J, Crewe-Brown H: Increase prevalence of severe malaria in HIV-infected adults in South Africa. Clin Inf Dis 2005, 41: 1631-1637.

15. Francesconi P, Fabiani M, Dente MG, Lukwiya M, Okwey R, Ouma J, Ochakachon R, Cian F and Declich S: HIV, malaria parasites, and acute febrile episode in Ugandan adults: a case-control study. AIDS 2001, 15: 2445-2450.

16. Patnaik P, Jere C, Miller W, Hoffman I, Wirima J, Pendame R: Effect of HIV-1 serostatut, HIV-1 RNA concentration, and CD 4 cell count on the incidence of malaria infection in a cohort of adult in rural Malawi. J Infect Dis 2005, 192: 984-991.

17. Flateau C, Le Loup G, Pialoux G : Consequences of HIV on malaria and therapeutic implication : systematic review. Lancet Infect Dis 2011, 11 : 541-556. 
18. French N, Nakiyingi J, Lugada E, Water C, Whitworth JA, Gilks CF: Increasing rates of malarial fever with deteriorating immune status in HIV-1-infected Ugandan adults. AIDS 2001, 15: 899-906.

19. Birku Y, Mekonnen E, Wolday D: Delayed clearance of Plasmodium falciparum in patients with human immunodeficiency virus co-infection treated with artemisinin. Ethip Med J 2002, 40 Suppl: 17-26.

20. Boudin C, Van Der Kolk M, Tchuinkam T, Gouagna LC, Bonnet S, Safeukui I, Mulder B, Meunier J-Y, Verhave J-P : Plasmodium falciparum transmission-blocking immunity under conditions of low and high endemicity in Cameroon. Parasite Immunol, 26: 105-110.

21. World Health Organization: Malaria and HIV interactions and their implications for Public Health Policy. Geneva, Switzerland: WHO; 2004.

22. Igbenghu C, Odaibo AB, David O, Onueghu J, Olisekodiaka J: Relationship between fever, malaria and HIV infection in a semi-urbain community in South-western Nigeria. Wrld J Med Science 2010, 5: 4144.

23. Hobbs C V, De La Vega P, Penzak S R, Van Vliet J, Krzych U, Sinnis P, Borkowsky W, Duffy P E : The effect of antiretrovirals on Plasmodium falciparum liver stages. AIDS 2013, 27: 1674-1677.

24. Van Geertruyden J P, Menten J, Colebunders R, Korenromp E, Umberto D: The impact of HIV-1 on the malaria parasite biomass in adults in sub-saharan Africa contributes to the emergence of the antimalarial drug resistance. BMC Malar j 2008, 7: 134.

25. Gasasira AF, Kamya MR, Achan J, Mebrahtu T, Kalyango JN, Charlebois E, Staedke SG, Kekitiinwa A, Rosenthal PJ: High risk of neutropenia in HIV-infected children following treatment with artesunate plus amodiaquine for uncomplicated malaria in Uganda. Clin Infect Dis 2008, 46: 985-991.

26. Kamya MR, Byakika-kibwika P, Gasasira AF, Havlir D, Rosenthal PJ, Dorsey G, Achan J: The effect of HIV on malaria in the context of the current standard of care for HIV-infected populations in Africa. Future Virol 2012, 7: 699-708.

27. Baheti R, Laddha P, Gehlot RS: Liver Involvement in falciparum malaria: a histo-pathological analysis. J Indian Acad Clin Med 2003, 4: 34-38.

28. Harinasuta T, Bunnag D: The clinical features of malaria. In: Wernsdorfer W H, McGregor I A, editors. Malaria: Principles and Practice of Malariology. Vol. 1. Edinburgh, UK: Churchill Livingstone; 1988. pp. 709-732.

29. Burtis C, Ashwood E, Border B: Tietz Fundamentals of Clinical Chemistry. 5th. Philadelphia, Pa, USA: Saunders Company; 2001. Liver functions; pp. 748-770.

30. Haleem N, Siddique AB, Alam I, Muhammad W, Haroom M, Safitullah Umer F: Assessment of liver function in malaria, typhoid and dengue diseases in Peshawar, Pakistan. J Entomol Zool Studies 2017, 05: 983-986.

31. Jain A, Kaushik R, Kaushik RM: Malaria hepatopathy: clinical profile and association with other malarial complications. Acta tropica 2016, 159: 95-105.

32. Woodford J, Shanks GD, Griffin P, Chalon S, McCarthy JS: The dynamics of liver function test abnormalities after malaria infection: a retrospective observation study. Am J Trop Med Hyg 2018, 
98: $1113-1119$.

33. Sherry BA, Alava G, Tracey KJ, Martiney J, Cerami A, Slater AF: Malaria-specific metabolite hemozoin mediates the release of several potent endogenous pyrogens (TNF, MIP-1, alpha, and MIP-1 beta) in vitro, and altered thermoregulation in vivo. J Inflamm 1995, 45: 85-96.

34. Amodu OK, Adeyemo AA, Olulese PE, Gbadegesin RA: Intraleucocytic malaria pigment and clinical severity of malaria in children. Trans R Soc Trop Med Hyg 1998, 92: 54-60.

35. Nguyen PH, Day N, Pram TD, Ferguson DJ, White NJ: Intraleucocytic malaria pigment and prognosis in severe malaria. Trans R Soc Trop Med Hyg 1995, 89: 200-204.

36. Parroche P, Lauv FN, Goutany N, Latz E, Monks BG, Visintin A, Halmen KA, Lamphier M, Olivier M, Bartholomeu DC, Gazzinelli Ricardo T: Malaria hemozoin is immunologically inert but radically enhances innate responses by presenting malaria DNA to Toll-like receptor-9. Proc Nat Acad Sci USA 2006, 104: 1919-1924.

37. Coban C, Ishii KJ, Kawai T, Hemmi H, Sato S, Uematsu S, Yamamoto M, Takeuchi O, Itagaki S, Kumar N, Horii T, Akira S: Toll-like receptor 9 mediates innate immune activation by the malaria pigment hemozoin. J Exp Med 2005, 201: 19-25.

38. Kubata BK, Eguchi N, Urade Y, Yamashita K, Mitamura T, Tai K, Hayaishi O, Horii T: Plasmodium falciparum produces Prostaglandins that are pyrogenic, somnogenic, and immunosuppressive substances in humans. J Exp Med 1998, 188: 1197-1202.

39. Anglaret X, Dakoury-Dogho N, Bonard D, Touré S, Combe P, Ouassa T, Menan H, N'Dri-Yoman T, Dabis F, Salomon R: Cause and empirical treatment of fever in HIV-infected adult out patients, Abidjam, Cote d'Ivoire. AIDS 2002, 16: 909-918.

40. Smith T, Hurt N, Teuscher T, Tanner M: Is fever a good sign for clinical malaria in surveys of endemic communities. Am J Trop Med Hyg 1995, 52: 306-310.

41. WHO: Global strategy for malaria control Geneva. World health Organisation; 1993.

42. Gosling RD, Drakeley CJ, Mwita A, Chandramohan D: Presumptive treatment of fever cases as malaria: help or hindrance for malaria control? BMC Malar J 2008, 7: 132.

43. WHO: Guidelines for the treatment of malaria. 2nd Edition, World health Organisation Geneva, 2010.

44. Snow RW, Menon A, Greenwood BM: Measuring morbidity from malaria. Ann Trop Med Parasitol 1989, 83: 321-323.

45. Okiro EA, Snow RW: The relationship between reported fever and Plasmodium falciparum infection in African children. BMC Malar J 2010, 9: 99.

46. Laishram DD, Stutton PL, Nanda N, Sharma VL, Sobti RC, Carlton JM: The complexity of malaria disease manifestations with a focus on asymptomatic malaria. BMC Malar J 2012, 11: 29.

47. Mc Guinness D, Koram K A, Bennett S, Wagner G: Clinical case definitions for malaria: clinical malaria associated with very low parasite densities in African infants. Trans R Soc Trop Med Hyg 1998, 92: 527-531. 
48. Peters RP, Zijlstra EE, Schijffelen MJ, Walsh AL, Joaki G, Kumwenda JJ, Kublin JG, Molyneux ME, Lewis DK : A prospective study of bloodstream infections as cause of fever in Malawi: clinical predictors and implications for management. Trop Med Int Health 2004, 9: 928-934.

49. Rougier C, Commenges D, Trape JF : Evidence of an age-dependant pyrogenic threshold of Plasmodum falciparum parasitaemia in highly endemic populations. Am J Trop Med Hyg 1996, 54: 613-619.

50. Nwanyanwu OC, Kumwenda N, Kazembe PN, Jumu S, Ziba C, Nkhoma WC, Redd SC: Malaria and human immunodeficiency virus infection among male employees of sugar estate in Malawi. Trans $\mathrm{R}$ Soc Trop Med Hyg 1997, 91: 567-569.

51. Centre Météorologique secondaire de Dschang (2004). Institut de Recherche Agronomique pour le développement, Ministère de le Recherche scientifique et de l'innovation Technologique (IRAD, MINRESI). Délégation régionale de l'Ouest, Dschang (Cameroun).

52. BUCREP/MINEPLADAT: Recensement et étude de la population du Cameroun. Rapport du 3ième recensement de la population (3e RGPH). Janvier 2010. 58-60.

53. De Saint Pol T: Comment mesurer la corpulence et le poids "idéal"? Histoire, intérêts et limites de l'indice de masse corporelle. Notes et Documents 2007-01, Paris, OSC.

54. OMS: Bench Aids for the diagnostic of malaria infection. 2nd edition; 2000, pp. 1-24.

55. OMS : Techniques de base pour le diagnostic microscopique du paludisme. Guide du stagiaire. Partie I. Genève; 1994, pp. 1-50.

56. Becton Dickinson Biosciences: Facscount System : User's guide. BD 2004, pp. 1-174.

57. Sysmex: Automated Hematology Analyser: KX-21N. Operator's manual 2006, pp. 1-316.

58. Bayer Health Care: Quantification de la charge virale VersantMT HIV-1 RNA 3.0 (bDNA), System 340 Bayer bDNA. Bayer Health Care Diagnostic Division. 2005, pp. 1-43.

59. Human: Diagnostic Worlwide: User manual. 2007, pp. 1-117.

60. Baird JK, Bangs M J, Maguire J D, Barcus MJ: 2- Epidemiological measures of risk of malaria. In Methods in molecular Medicine 2002, Vol 72: Malaria methods and Protocols, Ed Denise L. Doolan; Humana Press, Inc Totowa, NJ.

61. Smith T, Genton B, Baea K, Gibson N, Taime J, Narara A, Al-Yaman F, Beck H -P, Hii J, Alpers M: Relationships between Plasmodium falciparum infection and morbidity in a highly endemic area. Parasitology 1994a, 109: 539-549.

62. Smith T, Schellenberg J A, Hayes R: Attributable-fraction estimates and case definitions for malaria in endemic areas. Stat Med 1994b, 13: 2345-2358.

63. Rougier C, Fusai T, Pradines B, Trapes J- F : Comment évaluer la morbidité attribuable au paludisme en zone d'endémie? Rev Epidemiol Santé Publique 2005, 53 : 299-309.

64. Rougier C, Henry M- C, Trapes J F : Evaluation épidémiologique du paludisme en zone d’endémie. Méd Trop 2009, 69 : 123-142. 
65. Tchuinkam T, Simard F, Lélé-Defo E, Tune FB, Tateng AM, Antonio CN, Mpoame M, Toto JC, Njine T, Fontenille D, Awono HP: Bionomics of Anopheline species and malaria transmission dynamics along an altitudinal transct in Western Cameroon. BMC infect Diseases 2010, 10:119.

66. Doro-Altan A M, Taafo F, Fopa F, Buonomo E, Marazzi M C, Nielsen-Saines K, Orlando S, Scarcella P, Ciccacci F, Mancinelli S, Magnano San Lio M, Palombi L: An assessment of option B implementation for the prevention of mother to child transmission in Dschang, Cameroon: results from the DREAM cohort. Pan-African Med J 2016, 23: 72-81.

67. Biapo Kayo: Co-infection Paludisme et VIH/SIDA dans les services de médecine interne et des maladies infectieuses de l'hopital national du point « G ». Université de Bamako (Mali) ;Thèse de médecine, 2004. pp 82.

68. Grimwade K, French N, Mbatha DD, Zungu DD, Dedicoat M, Gilks CF: HIV infection as a cofactor for severe falciparum malaria in adults living in a region of unstable malaria transmission in South Africa. AIDS 2004, 18: 547-554.

69. Laufer KM, Van Oosterhout GJJ, Thesing CP, Thumba F, Zijlstra EE, Graham MS, Taylor ET, Plowe VC: Impact of HIV-associated immunosuppression on malaria Infection and Disease in Malawi. J Infect Dis 2006, 193: 872-878.

70. Hot A, Schmulewitz L, Viard JP, Lortholary O: Fever of unknown origin in HIV/AIDS patients. Infect Dis Clin North Am 2007, 21: 1013-1032.

71. Horsburgh CR: Mycobacterium avium complex infection in the acquired immunodeficiency syndrome. N Engl J Med 1991, 324: 1332-1338.

72. Richman DD, FischI MA, Grieco MH, Gottleib MS, Voderding PA: The toxicity of azidothymidine (AZT) in the treatment of patients with AIDS and AIDS-related complex. A double-blinded, placebo controlled trial. N Engl J Med 1987, 317: 192-197.

73. Institut National de la Statistique du Cameroun, ORC Macro: Enquêtes démographiques et de santé du Cameroun 2004. Juin Yaoundé et Calverton 2005.

\section{Tables}

Table 1: Comparison of the HIV-positive and HIV-negative patients' groups 


\begin{tabular}{|c|c|c|c|}
\hline & $\begin{array}{c}\text { HIV- } \\
\text { positive } \\
\text { patients }\end{array}$ & $\begin{array}{c}\text { HIV- } \\
\text { negative } \\
\text { patients }\end{array}$ & Comparison \\
\hline Total number of patients & $\begin{array}{c}729 \\
(37.2 \%)\end{array}$ & $\begin{array}{c}1231 \\
(62.8 \%)\end{array}$ & 1960 \\
\hline Mean ages (years) & $34.7 \pm 12.3$ & $25.7 \pm 22.2$ & $\begin{array}{c}(\mathrm{t}=-10.01, \mathrm{p}= \\
0.001)\end{array}$ \\
\hline $\begin{array}{l}\text { Percentage of Men } \\
\text { (Sex-ratio) }\end{array}$ & $\begin{array}{l}27.8 \% \\
(0.39)\end{array}$ & $\begin{array}{l}39.8 \% \\
(0.66)\end{array}$ & $\begin{array}{c}\left(\chi^{2}=28.65, P=\right. \\
0.001)\end{array}$ \\
\hline $\begin{array}{l}\text { Number of patients clinically diagnosed as seriously } \\
\text { sick and hospitalized for at least a day }\end{array}$ & $\begin{array}{c}98 \\
(13.44 \%)\end{array}$ & $\begin{array}{c}186 \\
(15.11 \%)\end{array}$ & $\begin{array}{c}\left(\chi^{2}=1.02, \mathrm{P}=\right. \\
0.31)\end{array}$ \\
\hline Average temperature $\left({ }^{\circ} \mathrm{C}\right)$ & 37.5 & 37.3 & $\begin{array}{c}(\mathrm{t}=2.79, \mathrm{p}= \\
0.76)\end{array}$ \\
\hline Number of patients with Headache & $\begin{array}{c}100 \\
(13.72 \%)\end{array}$ & $\begin{array}{c}195 \\
(15.84 \%)\end{array}$ & $\begin{array}{c}\left(\chi^{2}=1.62, P=\right. \\
0.20)\end{array}$ \\
\hline Number of patients with joint pains & $\begin{array}{c}118 \\
(16.19 \%)\end{array}$ & $\begin{array}{c}204 \\
(16.57 \%)\end{array}$ & $\begin{array}{c}\left(\chi^{2}=0.50, P=\right. \\
0.82)\end{array}$ \\
\hline Number of patients with abdominal pains & $\begin{array}{c}168 \\
(23.04 \%)\end{array}$ & $\begin{array}{c}190 \\
(15.43 \%)\end{array}$ & $\begin{array}{c}\left(\chi^{2}=17.76, P<\right. \\
0.001)\end{array}$ \\
\hline Number of patients with convulsion & $\begin{array}{c}99 \\
(13.58 \%)\end{array}$ & $\begin{array}{c}184 \\
(14.95 \%)\end{array}$ & $\begin{array}{c}\left(\chi^{2}=0.69, P=\right. \\
0.41)\end{array}$ \\
\hline Number of patients with nausea & $\begin{array}{c}136 \\
(18.65 \%)\end{array}$ & $\begin{array}{c}208 \\
(16.90 \%)\end{array}$ & $\begin{array}{c}\left(\chi^{2}=0.98, P=\right. \\
0.32)\end{array}$ \\
\hline $\begin{array}{l}\text { Number of Plasmodium-positive patients (Plasmodial } \\
\text { infection rates) }\end{array}$ & $\begin{array}{c}6 \\
(0.823 \%)\end{array}$ & $\begin{array}{c}101 \\
(8.204 \%)\end{array}$ & $\begin{array}{c}\left(\chi^{2}=48.34, \mathrm{P}<\right. \\
0.001)\end{array}$ \\
\hline $\begin{array}{l}\text { Arithmetic means of malaria } \\
\text { parasitaemia (Parasites/pl) }\end{array}$ & $\begin{array}{l}21 \pm \\
299\end{array}$ & $4537 \pm 35737$ & $\begin{array}{c}(\mathrm{U}= \\
4.53 \times 10^{5}, \mathrm{P}= \\
0.001)\end{array}$ \\
\hline $\begin{array}{l}\text { Geometric means of malaria } \\
\text { parasitaemia (Parasites/ } \mu \mathrm{l} \text { ) }\end{array}$ & 1.05 & 1.28 & $(\mathrm{t}=7.45, \mathrm{P}=$ \\
\hline
\end{tabular}

Table 2: Effect of malaria infection on the liver function of HIV-positive patients 
Liver enzyme secretions *
Malaria status

Total

\begin{tabular}{cc}
$\begin{array}{c}\text { Plasmodium-positive } \\
\text { patients }\end{array}$ & $\begin{array}{c}\text { Plasmodium-negative } \\
\text { patients }\end{array}$ \\
\hline
\end{tabular}

4

486

490

$34 \pm 11.17$

$42.15 \pm 45.63$

( Mann-Whitney $\mathrm{U}=903 ; \mathrm{p}=$ 0.87 )

Mean of GPT (UI/L)
$36.24 \pm 31.32$
(Mann-Whitney $\mathrm{U}=834.5 ; \mathrm{p}=$ 0.63 )

* $:$ GOT $=$ Glutamo-Oxalo-acetate Transferase, $\mathrm{GPT}=$ Glutamo- Pyruvate Transferase

Table 3: Comparison of the status of febrile and non-febrile HIV-positive patients' groups 


\begin{tabular}{|c|c|c|c|}
\hline & $\begin{array}{c}\text { HIV+ and } \\
\text { Febrile/symptomatic } \\
\text { patients }\end{array}$ & $\begin{array}{c}\text { HIV+ and } \\
\text { Non-febrile/ } \\
\text { asymptomatic } \\
\text { patients } \\
\end{array}$ & Comparison \\
\hline Total number of patients & 119 & 610 & 729 \\
\hline Mean Temperature $\left({ }^{\circ} \mathrm{C}\right)$ & $38.59 \pm 0.59$ & $36.73 \pm 0.59$ & $\begin{array}{l}(t=-22.82 \\
p<0.001)\end{array}$ \\
\hline Mean ages (/year) & $33.11 \pm 10.05$ & $34.96 \pm 12.73$ & $\begin{array}{l}(\mathrm{t}=1.75, \mathrm{p} \\
\quad=0.08)\end{array}$ \\
\hline $\begin{array}{l}\text { Percentage of Male } \\
\text { (Sex-ratio) }\end{array}$ & $\begin{array}{l}22.69 \% \\
(0.36)\end{array}$ & $\begin{array}{l}28.85 \% \\
(0.41)\end{array}$ & $\begin{array}{l}\left(\chi^{2}=1.88\right. \\
p=0.17)\end{array}$ \\
\hline $\begin{array}{l}\text { Mean viral loads (copies/ml) } \\
\text { (Number of patients with > } 100000 \\
\text { copies/ml) }\end{array}$ & $\begin{array}{l}2.14 \times 10^{5} \pm 208490 \\
\quad(68(57.1 \%))\end{array}$ & $\begin{array}{l}1.81 \times 10^{5} \pm 327199 \\
\quad(267(43.8 \%))\end{array}$ & $\begin{array}{l}(\mathrm{t}=-1.08, \mathrm{p} \\
\quad=0.28) \\
\left(\chi^{2}=12.31\right. \\
\mathrm{p}=0.02)\end{array}$ \\
\hline Mean total WBCs count (cell/ $\mu \mathrm{l})$ * & $5.2 \times 10^{3} \pm 2.60 \times 10^{3}$ & $\begin{array}{l}5.7 \times 10^{3} \pm \\
2.67 \times 10^{3}\end{array}$ & $\begin{array}{l}(\mathrm{t}=0.56, \mathrm{p} \\
\quad=0.57)\end{array}$ \\
\hline $\begin{array}{l}\text { Mean CD } 4 \text { count }(\text { cell } / \mu l) \\
\text { (Number of patients with }<350 \text { cell } / \mu l \text { ) }\end{array}$ & $\begin{array}{c}226 \pm 221 \\
(99(83.2 \%))\end{array}$ & $\begin{array}{c}305 \pm 273 \\
(436(71.5 \%))\end{array}$ & $\begin{array}{c}(t=3.06, p \\
=0.003) \\
\left(\chi^{2}=\right. \\
20.56, p= \\
0.007)\end{array}$ \\
\hline Mean RBCs count $($ cell $/ \mu \mathrm{l}) *$ & $\begin{array}{l}3.83 \times 10^{6} \pm \\
0.72 \times 10^{6}\end{array}$ & $\begin{array}{c}4.03 \times 10^{6} \pm \\
0.70 \times 10^{6}\end{array}$ & $\begin{array}{l}(\mathrm{t}=2.81, \mathrm{p} \\
=0.005)\end{array}$ \\
\hline Mean $\mathrm{Hb}$ densities $(\mathrm{g} / \mathrm{dl}) *$ & $\begin{array}{l}10.37 \pm \\
2.14\end{array}$ & $11.36 \pm 2.04$ & $\begin{array}{l}(\mathrm{t}=4.62, \mathrm{p} \\
\quad<0.001)\end{array}$ \\
\hline Mean BMI $\left(\mathrm{kg} / \mathrm{m}^{2}\right)^{*}$ & $\begin{array}{l}23.80 \pm \\
5.51\end{array}$ & $23.37 \pm 4.55$ & $\begin{aligned}(\mathrm{t} & =-0.92, \mathrm{p} \\
& =0.36)\end{aligned}$ \\
\hline $\begin{array}{l}\text { Number of Plasmodium-positive patients } \\
\text { (Mean Plasmodial infection rates) }\end{array}$ & $\begin{array}{c}01 \\
(0.840 \%)\end{array}$ & $\begin{array}{c}05 \\
(0.819 \%)\end{array}$ & $\begin{array}{c}06 \\
\text { (Exact } \\
\text { Ficher } \\
\text { Test, } \\
\mathrm{p}=0.65 \text { ) }\end{array}$ \\
\hline $\begin{array}{l}\text { Arithmetic means of malaria } \\
\text { parasitaemia (Parasites/pl) }\end{array}$ & $15.9 \pm 173.3$ & $(\mathrm{U}=0.2$ & $\left(\mathrm{U}=0.27 \times 10^{5}, \mathrm{P}=0.78\right)$ \\
\hline $\begin{array}{l}\text { Geometric means of malaria } \\
\text { parasitaemia (Parasites/pl) }\end{array}$ & 1.07 & 1.04 & $\begin{array}{l}(\mathrm{t}=0.33, \mathrm{p} \\
\quad=0.74)\end{array}$ \\
\hline
\end{tabular}


* $:$ WBC $=$ Total White Blood Cells $; \mathrm{RBC}=$ Red Blood Cells $; \mathrm{Hb}=$ Haemoglobin $; \mathrm{BMI}=$ Body Mass Index ; MAFE = Malaria-attributable fraction of fever episodes

\section{Supplementary Files}

This is a list of supplementary files associated with this preprint. Click to download.

- eq1.jpg

- eq3.jpg

- eq2.jpg 